\title{
Knowledge, attitude and practice of antibiotic use among university students: a cross sectional study in UAE
}

\author{
Ammar Jairoun ${ }^{1 *} \mathbb{D}$, Nageeb Hassan ${ }^{1}$, Abdelazim Ali ${ }^{1}$, Obaida Jairoun² and Moyad Shahwan ${ }^{1}$
}

\begin{abstract}
Background: Antibiotic resistance became a marker of irrational and overuse of these medicines in many countries. This study aims to evaluate the knowledge, attitude and practice (KAP) of medical students (MS) and non-medical students (NS) towards antibiotic use in the United Arabs Emirates (UAE).

Method: A descriptive cross-sectional study was conducted amongst 1200 MS and NS from Ajman University in UAE. A self-administered questionnaire was used to assess the knowledge, attitude and practice of antibiotic use. The later was composed into knowledge, attitude and practice of antibiotic use. Descriptive analysis was used to analyse the qualitative variables while quantitative variables were summarised using mean \pm Standard Deviation $( \pm S D)$. A Chi-square test was used to compare differences in the proportions of qualitative variables. Unpaired student's t-test was used to test the average differences in quantitative variables across medical and non-medical students. A $p<0.05$ was considered statistically significant.
\end{abstract}

Results: One thousand two hundred students (MS: 600 and NS: 600) were considered valid for analysis. On average, participants scored higher in attitude score followed by knowledge and practice scores. The average attitude score was 76\% (95\% Cl: [75, 78\%]) compared to 59\% for knowledge (95\% Cl: [58, 60\%]) and 45\% (95\% Cl: [44, 47\%]) for practice. The results suggest that overall, medical students scored remarkably better than non-medical students on KAP of antibiotic use, respectively $(p=0.0001),(p=0.000)$ and $(p=0.002)$.

Conclusion: The students' knowledge, attitude and practice regarding antibiotic use, which drive the practice of self-medication, reflect a gap in medical curricula in UAE institutes and medical colleges.

Keywords: Antibiotic usage, Knowledge, Attitude, Practice, KAP, Medical students

\section{Background}

Antibiotics were called "magic bullets" for quite some time; however, these magic bullets were not always magical enough to survive some serious downsides. The use and misuse of antibiotics induce selection pressure, resulting in the development of resistance traits in bacterial populations [1]. However, the problem was not the antibiotics themselves as they remained one of the most effective weapons against diseases; in fact, the problem lied in the drugs' use. Overusing antibiotics or using them irrationally can easily result not only in the emergence of resistant bacterial strains but also in adverse

\footnotetext{
* Correspondence: Dr_ammar_91_@hotmail.com

${ }^{1}$ College of Pharmacy and Health Sciences, Ajman University, Ajman, UAE Full list of author information is available at the end of the article
}

reactions and can also result in an economical burden on the national health system [2]. The World Health Organization set the theme of the World Health Day as Combat Antimicrobial Resistance: No Action Today, No Cure Tomorrow' [3]. According to a September 2013 report from the U.S. Center for Disease Control and Prevention (CDC), treatment of antibiotic-resistant infections adds $\$ 35$ billion to health care costs and 8 million hospital days per year in the United States [4]. Antibiotic use might be influenced by several factors such as unregulated drug availability, relaxed health policies concerning regulations on antibiotic use, procurement of antibiotics without prescription (overthe-counter acquisition), patients' knowledge and attitudes towards antibiotic use, self-medication, physicians'

(c) The Author(s). 2019 Open Access This article is distributed under the terms of the Creative Commons Attribution 4.0 International License (http://creativecommons.org/licenses/by/4.0/), which permits unrestricted use, distribution, and reproduction in any medium, provided you give appropriate credit to the original author(s) and the source, provide a link to the Creative Commons license, and indicate if changes were made. The Creative Commons Public Domain Dedication waiver (http://creativecommons.org/publicdomain/zero/1.0/) applies to the data made available in this article, unless otherwise stated. 
knowledge and experiences and patient-prescriber interaction. Therefore, controlling antibiotic use requires feasible means of intervention. Many strategies have been proposed for the use of antibiotics such as a formulary replacement or restriction, health care provider education, feedback activities, approval requirement from an infectious disease specialist for the drug prescription and a more rational use of antimicrobial agents all over the world $[5,6]$. The students can play a crucial role in reducing the inappropriate use of antibiotics; in this context, an increasing number of research reports in the literature have focused their attention on investigating the KAP of medical and non-medical students towards antibiotics use. A survey of 2500 medical and non-medical students in China indicated that medical students performed better than non-medical students in terms of knowledge and attitude towards antibiotic use [7]. This is similar to the findings of another study conducted in Chennai among medical and paramedical students [8]. In a study in Malaysia by Ahmad et al. [9] with third- and fourth-year pharmacy students, sufficient knowledge but poor attitude of pharmacy students regarding antibiotics use was reported. Other studies in India $[10,11]$ reported poor knowledge regarding the antibiotic spectra, indications, side effect and their correct use. Moreover, students' knowledge regarding antibiotic resistance and antibiotic prescribing was moderate as well as the attitude toward the cause of resistance [12]. Another study [13] revealed good understanding and awareness regarding antibiotic resistance; this was consistent with the study of Khan and Banu [14] which revealed that majority of the students were aware of antimicrobial resistance and its consequences. Another cross-sectional study conducted among university undergraduates to assess their knowledge and practice towards antibiotic use and reported poor knowledge of the right sources of antibiotic; furthermore, majority of them used the same antibiotics as previously prescribed by their doctors to treat their perceived infections while $51.2 \%$ kept leftover antibiotics for future use [15]. In Italy, a study performed in Torino University among health care profession students also revealed the existing gap between knowledge and practice [16].

\section{Aim of the study}

To our knowledge, no study was conducted in Arab countries and Gulf Cooperation Council (GCC) countries, particularly in United Arab Emirates (UAE) evaluating the Knowledge, attitude and practice (KAP) of medical students towards antibiotic use. Therefore, this study aims to investigate medical students' KAP in relation to antibiotic use by controlling with non-medical students.

\section{Methods}

A cross-sectional survey carried out among randomly selected MS and NS from Ajman University in the UAE from January to May 2015. The targeted respondents for the survey were undergraduate students from first to fifth years in medical colleges and from first to fifth year in non-medical colleges. In order to overcome the multiplicity of sources of data collection that might confuse the assessment of study results, the directory of Admission and Registration Department of Ajman University was used as the sampling frame. This directory was considered a pre-existing frame with officially recognized and listed information on students' names, university ID numbers, major, age, gender, nationality and contact numbers that were updated regularly. From the Excel sheet of the sampling frame, 600 MS from faculties of medical colleges and a paired 600 NS from faculties of non-medical colleges were enrolled in this study. The method of "Simple random sample selection" was followed. In this method, individuals were selected randomly and not more than once to avoid bias that could negatively affect the result's validity. A self-administered questionnaire was distributed randomly to the participants during lectures (at the end of their classes) and a signed consent form was obtained from the participants.

After referring to previous similar studies [7, 11]. regarding KAP of antibiotic use in the literature, a structured self-administered was designed and adapted to cover all the main key points of the research and in a way that suit with local population of UAE.

The questionnaire was then reviewed and assessed by subject experts for its content, design, relevance, readability and comprehension. The questionnaire was validated by seven lecturers from the discipline of clinical pharmacy at Ajman university and it was examined for content relevance and appropriateness. Minor modifications were done based on their comments. Moreover, quantitative content validity of the instrument was ascertained based on Lawshe's Content Validity [17]. A content validity ration (CVR) was calculated for each item and all items reported 0.71 CVR score. Items with CVR score of 0.7 or above were selected acceptable and if the item does not reach this threshold, it would normally be deleted from the final instrument [18]. Then, content validity index (CVI) was obtained by calculating the mean of the CVR values for all items meeting the CVR threshold of 0.70 and retained for the final instrument. The final reported CVI value for the instruments was 0.71 which indicating acceptable content validity of the entire instrument [19]. In addition, for reliability, a pilot study was done on 100 students from Ajman university and necessary changes were made accordingly. The participants who were participated in pilot study 
have been excluded from final analysis. The reliability analysis of the instrument was performed by calculating Cronbach's $\alpha$ value. The Cronbach's $\alpha$ value of the questionnaire was 0.73 , indicating acceptable internal consistency.

The first section covered participants' demographic data such as major and grade of education. The second section covered knowledge of antibiotic use and comprised 12 questions. The third section assessed the attitude of respondents regarding antibiotic use and had six questions. The fourth section explored the self-medication practices of students and had 15 questions.

All questions were coded and then imported to SPSS version 23 for analysis. Descriptive analysis was used to analyse the qualitative variables while quantitative variables were summarized using mean \pm Standard Deviation $( \pm \mathrm{SD})$. Graphical representations were provided for all relevant variables. The Chi-square test was used to compare differences in the proportions of qualitative variables. Unpaired student's t-tests were used to test the average differences in quantitative variables across medical and non-medical students. A $p<0.05$ was considered statistically significant. Three scores were created to measure the knowledge, attitude and practice of antibiotic use. Each score was defined as the proportion of questions for which the answers were correct. These three scores range from 0 to $100 \%$ and might be used as good approximation of the overall KAP. Shapiro wilk test was carried out to test the normality of the knowledge, attitude and practice scores. The results showed that there were no statistically significant deferens from the normal distribution for the knowledge score $(P=0.87)$, attitude score $(\mathrm{P}=0.077)$, and practice score $(\mathrm{P}=0.063)$.

\section{Results}

\section{Characteristics of the study population}

A total of 1200 subjects participated in the study and completed the entire questionnaire. Among these participants, 600 (50\%) were medical students constituting the primary target group and $600(50 \%)$ were non-medical students mainly used as control. Fifty-five percent $(55.5 \%)$ were first-year students and $44.5 \%$ were final-year students.

\section{Knowledge on antibiotic use: analysis of overall knowledge score}

The average knowledge score was $59 \%$ with a $95 \%$ confidence interval (CI) [58,60\%] This means that on a knowledge scale of 0 to 100, participants scored an average of 59 points in the knowledge of antibiotic use. Table 1 shows the distribution of knowledge scores according to the major. MS scored relatively higher than NS in knowledge of antibiotic use $(p=0.000)$. Their average score was $65 \%$ compared to $53 \%$ of NS. The same pattern of results was observed between first-year MS and NS $(p=0.000)$ and final-year MS and NS $(\mathrm{p}=0.000)$ (see Table 1 and Fig. 1). The results of each of the questions related to the knowledge of antibiotic usage among MS and NS were analysed using $X^{2}$ test (see Table 2).

\section{Attitude on antibiotic use: analysis of overall attitude score}

The average attitude core was $76 \%$ with a $95 \%$ confidence interval (CI) [75, 78\%] This means that on an attitude scale of 0 to 100, participants scored an average of 76 points in the attitude towards antibiotic use. Table 2 shows the distribution of attitude score according to the major. MS scored relatively higher than NS in attitude towards antibiotic use $(p=0.000)$. Their average score was $80 \%$ compared to $73 \%$ in NS. The same pattern of results was observed between first year MS and NS $(p=0.001)$ and final MS and NS ( $\mathrm{p}=0.000)$ (see Table 1 and Fig. 2). The results of each of the questions related to the attitude towards antibiotic usage among medical and non-medical students were analysed using $\chi^{2}$ test (see Table 3 ).

\section{Practice on antibiotic use: analysis of overall practice score}

The average practice core was $45 \%$ with a $95 \%$ CI [ 44 , 47\%]. This means that on a practice scale of 0 to 100 , participants scored an average of 45 points in the practice of antibiotic use. MS scored relatively higher than NS in the practice of antibiotic use $(p=0.002)$. Their average score was $47 \%$ compared to $43 \%$ in NS. The same pattern of results was observed between final-year MS and NS $(p=0.001)$ while there was no significant difference between first-year MS and NS $(p=0.232)$ (see

Table 1 Medical and non-medical students average score on knowledge, attitude and practice of antibiotic use

\begin{tabular}{|c|c|c|c|c|c|c|c|c|c|c|}
\hline \multirow{2}{*}{$\begin{array}{l}\text { Student } \\
\text { Score }\end{array}$} & \multirow{2}{*}{$\begin{array}{l}\text { Overall } \\
\text { average } \\
95 \% \mathrm{Cl}\end{array}$} & \multicolumn{3}{|c|}{ Whole average $95 \% \mathrm{Cl}$} & \multicolumn{3}{|c|}{ 1st year average $95 \% \mathrm{Cl}$} & \multicolumn{3}{|c|}{ Final year average 95\% Cl } \\
\hline & & MS & NS & $p$ & MS & NS & $p$ & MS & NS & $P$ \\
\hline Knowledge & $59(58-60)$ & $65(64-67)$ & $53(52-54)$ & 0.000 & $59(57-60)$ & $53(51-54)$ & 0.000 & $75(74-77)$ & $53(51-54)$ & 0.000 \\
\hline Attitude & $76(75-78)$ & $80(78-81)$ & $73(71-75)$ & 0.000 & $77(75-79)$ & $72(69-74)$ & 0.001 & $84(82-86)$ & $75(72-77)$ & 0.000 \\
\hline Practice & $45(44-47)$ & $47(46-49)$ & $43(41-45)$ & 0.002 & $47(44-49)$ & $45(42-47)$ & 0.232 & $49(46-51)$ & $42(39-45)$ & 0.001 \\
\hline
\end{tabular}

*p < 0.05; \#Significance; 95\% Cl confidence interval 


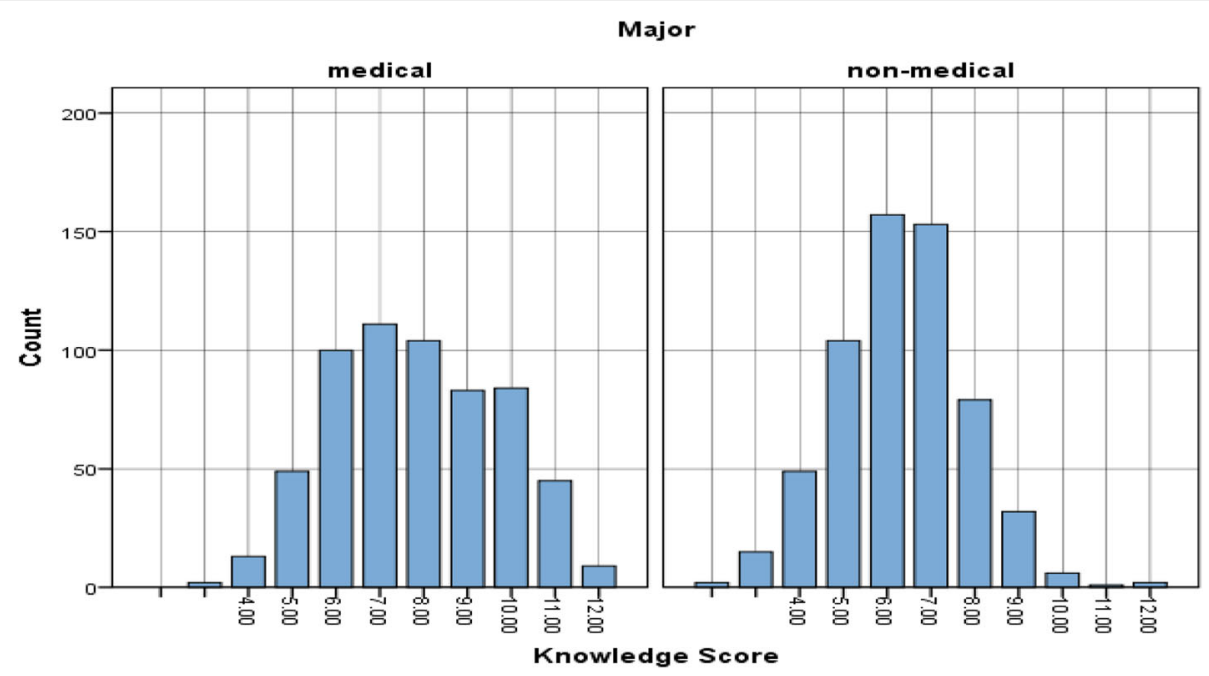

Fig. 1 Histogram of knowledge score by major. Figure 1 shows the distribution of overall knowledge scores among medical and non medial students. The values in the $x$ axis represents the total number of correct answers. $Y$ axis represents the count

Table 2 Number and percentage of the questions on the knowledge of antibiotic use

\begin{tabular}{|c|c|c|c|c|c|c|c|c|c|c|c|c|c|}
\hline \multirow[t]{2}{*}{ Question (correct response) } & \multirow{2}{*}{$\begin{array}{l}\text { Total } \\
\%(n / \\
N)\end{array}$} & \multicolumn{4}{|c|}{ Whole n (\%) } & \multicolumn{4}{|c|}{1 st year n (\%) } & \multicolumn{4}{|c|}{ Final year n (\%) } \\
\hline & & MS & NS & $x^{2}$ & $\mathrm{p}$ & MS & NS & $x^{2}$ & $p$ & MS & NS & $x^{2}$ & $p$ \\
\hline $\begin{array}{l}\text { Are there bacteria in human body which are } \\
\text { good for our health? (Yes) }\end{array}$ & $\begin{array}{l}1169 \\
(97.4 \%)\end{array}$ & $\begin{array}{l}594 \\
(99 \%)\end{array}$ & $\begin{array}{l}575 \\
(95.8 \%)\end{array}$ & 12 & 0.001 & $\begin{array}{l}361 \\
(98.6 \%)\end{array}$ & $\begin{array}{l}281 \\
(93.7 \%)\end{array}$ & 11.7 & 0.001 & $\begin{array}{l}233 \\
(99.6 \%)\end{array}$ & $\begin{array}{l}294 \\
(98 \%)\end{array}$ & 2.5 & 0.113 \\
\hline $\begin{array}{l}\text { Can antibiotics be used to cure Infections } \\
\text { caused by bacteria (Yes) }\end{array}$ & $\begin{array}{l}1097 \\
(91.4 \%)\end{array}$ & $\begin{array}{l}560 \\
(93.3 \%)\end{array}$ & $\begin{array}{l}537 \\
(89.5 \%)\end{array}$ & 5.6 & 0.018 & $\begin{array}{l}332 \\
(90.7 \%)\end{array}$ & $\begin{array}{l}260 \\
(86.7 \%)\end{array}$ & 2.7 & 0.1 & $\begin{array}{l}228 \\
(97.4 \%)\end{array}$ & $\begin{array}{l}277 \\
(92.3 \%)\end{array}$ & 6.7 & 0.01 \\
\hline $\begin{array}{l}\text { Can antibiotics be used to cure infections } \\
\text { caused by viruses (No) }\end{array}$ & $\begin{array}{l}576 \\
(48 \%)\end{array}$ & $\begin{array}{l}395 \\
(65.8 \%)\end{array}$ & $\begin{array}{l}81 \\
(30.2 \%)\end{array}$ & 153 & 0.000 & $\begin{array}{l}215 \\
(58.7 \%)\end{array}$ & $\begin{array}{l}93 \\
(31 \%)\end{array}$ & 51 & 0.000 & $\begin{array}{l}180 \\
(77 \%)\end{array}$ & $\begin{array}{l}88 \\
(29.3 \%)\end{array}$ & 119 & 0.000 \\
\hline $\begin{array}{l}\text { Do you think the use of antibiotics will speed } \\
\text { up the recovery of cold, cough and other } \\
\text { diseases (No) }\end{array}$ & $\begin{array}{l}356 \\
(29.7 \%)\end{array}$ & $\begin{array}{l}205 \\
(34.2 \%)\end{array}$ & $\begin{array}{l}151 \\
(25.2 \%)\end{array}$ & 11.6 & 0.001 & $\begin{array}{l}112 \\
(30.6 \%)\end{array}$ & $\begin{array}{l}80 \\
(26.7 \%)\end{array}$ & 1.2 & 0.256 & $\begin{array}{l}93 \\
(39.7 \%)\end{array}$ & $\begin{array}{l}71 \\
(23.7 \%)\end{array}$ & 16 & 0.000 \\
\hline $\begin{array}{l}\text { Antibiotics are obtainable Without } \\
\text { interference of a doctor at drug stores or } \\
\text { pharmacies (No) }\end{array}$ & $\begin{array}{l}661 \\
(55.1 \%)\end{array}$ & $\begin{array}{l}318 \\
(53 \%)\end{array}$ & $\begin{array}{l}343 \\
(57.2 \%)\end{array}$ & 2.1 & 0.147 & $\begin{array}{l}213 \\
(58.2 \%)\end{array}$ & $\begin{array}{l}185 \\
(61.7 \%)\end{array}$ & 0.83 & 0.364 & $\begin{array}{l}105 \\
(45 \%)\end{array}$ & $\begin{array}{l}158 \\
(52.7 \%)\end{array}$ & 3.2 & 0.074 \\
\hline Have you heard of resistance of bacteria (Yes) & $\begin{array}{l}914 \\
(76.2 \%)\end{array}$ & $\begin{array}{l}507 \\
(84.5 \%)\end{array}$ & $\begin{array}{l}407 \\
(67.8 \%)\end{array}$ & 46 & 0.000 & $\begin{array}{l}285 \\
(77.9 \%)\end{array}$ & $\begin{array}{l}194 \\
(64.7 \%)\end{array}$ & 14.2 & 0.000 & $\begin{array}{l}222 \\
(95 \%)\end{array}$ & $\begin{array}{l}213 \\
(71 \%)\end{array}$ & 49.6 & 0.000 \\
\hline $\begin{array}{l}\text { Do you think frequent use of antibiotics will } \\
\text { decrease the treatment when using the } \\
\text { antibiotic again (Yes) }\end{array}$ & $\begin{array}{l}913 \\
(76.1 \%)\end{array}$ & $\begin{array}{l}487 \\
(81.2 \%)\end{array}$ & $\begin{array}{l}426 \\
(71 \%)\end{array}$ & 17 & 0.000 & $\begin{array}{l}294 \\
(80.3 \%)\end{array}$ & $\begin{array}{l}203 \\
(67.7 \%)\end{array}$ & 14 & 0.000 & $\begin{array}{l}193 \\
(82.5 \%)\end{array}$ & $\begin{array}{l}223 \\
(74.3 \%)\end{array}$ & 5.1 & 0.024 \\
\hline $\begin{array}{l}\text { Is the efficacy better if the antibiotics are } \\
\text { newer and the price is higher (No) }\end{array}$ & $\begin{array}{l}833 \\
(69.4 \%)\end{array}$ & $\begin{array}{l}435 \\
(72.5 \%)\end{array}$ & $\begin{array}{l}398 \\
(66.3 \%)\end{array}$ & 5.4 & 0.020 & $\begin{array}{l}258 \\
(70.5 \%)\end{array}$ & $\begin{array}{l}200 \\
(66.7 \%)\end{array}$ & 1.1 & 0.289 & $\begin{array}{l}177 \\
(75.6 \%)\end{array}$ & $\begin{array}{l}198 \\
(66 \%)\end{array}$ & 5.8 & 0.016 \\
\hline Amoxicillin is antibiotic (Yes) & $\begin{array}{l}717 \\
(59.8 \%)\end{array}$ & $\begin{array}{l}414 \\
(69 \%)\end{array}$ & $\begin{array}{l}303 \\
(50.5 \%)\end{array}$ & 42.7 & 0.000 & $\begin{array}{l}193 \\
(52.7 \%)\end{array}$ & $\begin{array}{l}140 \\
(46.7 \%)\end{array}$ & 2.4 & 0.119 & $\begin{array}{l}221 \\
(94.4 \%)\end{array}$ & $\begin{array}{l}163 \\
(54.3 \%)\end{array}$ & 104.7 & 0.000 \\
\hline Penicillin is antibiotic (Yes) & $\begin{array}{l}685 \\
(57.1 \%)\end{array}$ & $\begin{array}{l}381 \\
(63.5 \%)\end{array}$ & $\begin{array}{l}304 \\
(50.7 \%)\end{array}$ & 20.2 & 0.000 & $\begin{array}{l}193 \\
(52.7 \%)\end{array}$ & $\begin{array}{l}166 \\
(55.3 \%)\end{array}$ & 0.449 & 0.503 & $\begin{array}{l}188 \\
(80.3 \%)\end{array}$ & $\begin{array}{l}138 \\
(46 \%)\end{array}$ & 65.2 & 0.000 \\
\hline Tetracycline is antibiotic (Yes) & $\begin{array}{l}353 \\
(29.4 \%)\end{array}$ & $\begin{array}{l}237 \\
(39.5 \%)\end{array}$ & $\begin{array}{l}116 \\
(19.3 \%)\end{array}$ & 58.7 & 0.000 & $\begin{array}{l}73 \\
(19.9 \%)\end{array}$ & $\begin{array}{l}63 \\
(21 \%)\end{array}$ & 0.113 & 0.737 & $\begin{array}{l}164 \\
(70.1 \%)\end{array}$ & $\begin{array}{l}53 \\
(17.7 \%)\end{array}$ & 149.7 & 0.000 \\
\hline $\begin{array}{l}\text { Definition of drug susceptibility testing of } \\
\text { bacteria (Yes) }\end{array}$ & $\begin{array}{l}220 \\
(18.3 \%)\end{array}$ & $\begin{array}{l}169 \\
(28.2 \%)\end{array}$ & $\begin{array}{l}51 \\
(8.5 \%)\end{array}$ & 77.5 & 0.000 & $\begin{array}{l}53 \\
(14.5 \%)\end{array}$ & $\begin{array}{l}29 \\
(9.7 \%)\end{array}$ & 3.5 & 0.060 & $\begin{array}{l}116 \\
(49.6 \%)\end{array}$ & $\begin{array}{l}22 \\
(7.3 \%)\end{array}$ & 122.4 & 0.000 \\
\hline
\end{tabular}




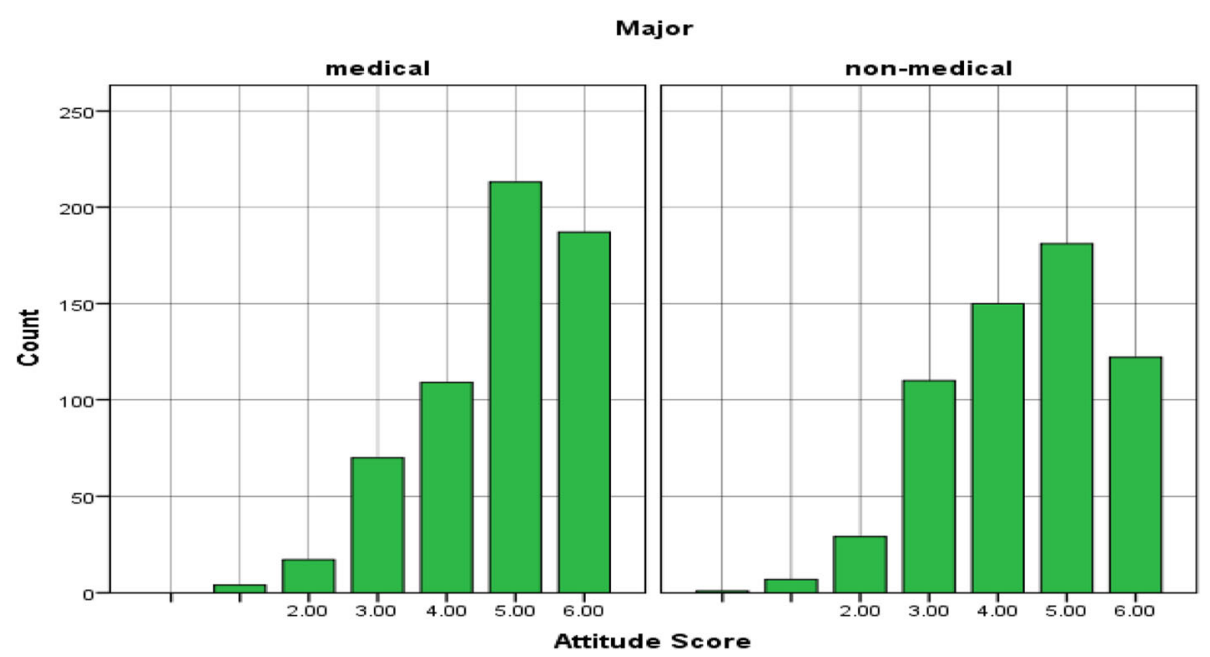

Fig. 2 Histogram of attitude score by major. Figure 2 shows the distribution of overall attitude scores among medical and non medial students. The values in the $x$ axis represents the total number of correct answers. $Y$ axis represents the count

Table 1 and Fig. 3). The results of each of the questions related to practice of antibiotic usage among MS and NS students were analysed using $\chi^{2}$ test (see Table 4).

\section{Discussion}

As per our knowledge, this is the first large-scale study assessing the KAP of antibiotic use among MS and NS students in the Arab countries, the Gulf region and UAE. On an average, MS and NS scored higher in attitude score followed by knowledge score and practice score. The average attitude score was 76\% (95\% CI: [75, $78 \%])$ compared to $59 \%$ for knowledge score (95\% CI: [58, 60\%]) and 45\% (95\% CI: [44, 47\%]) for practice score. The study results confirmed statistically significant differences in the KAP of antibiotic use among MS and NS. Regarding knowledge of antibiotic use, the results showed that overall MS scored significantly higher than NS $(p=0.000)$. The same pattern of results was observed between first-year MS and first-year NS ( $p=$ $0.000)$ and final-year MS and final-year NS ( $\mathrm{p}=0.000)$. This agrees with other findings about knowledge of antibiotic use reported in the literature [7, 8, 20, 21]. Other studies in Malaysia [9, 13] among final-year dentistry and pharmacy students reported a good knowledge of antibiotic use among medical students. These findings are parallel with the study in Italy [16] amongst students of a school of medicine that reported good knowledge about antibiotics use. Therefore, these results suggest that medical students have more knowledge about antibiotics than other students or the public. However, some studies showed that knowledge of antibiotic use was moderate to poor among medical students [1012, 22-24].

In this study, although overall MS scored better than NS regarding the knowledge of antibiotic use, MS had poor knowledge that may results in antibiotic abuse.

Table 3 Number and percentage of the questions on the attitude of antibiotic use

\begin{tabular}{|c|c|c|c|c|c|c|c|c|c|c|c|c|c|}
\hline \multirow[t]{2}{*}{ Question (correct response) } & \multirow{2}{*}{$\begin{array}{l}\text { Total } \\
\%(\mathrm{n} / \\
\mathrm{N})\end{array}$} & \multicolumn{4}{|c|}{ Whole n (\%) } & \multicolumn{4}{|c|}{ 1st year n (\%) } & \multicolumn{4}{|c|}{ Final year $n(\%)$} \\
\hline & & MS & NS & $x^{2}$ & $p$ & MS & NS & $x^{2}$ & $p$ & MS & NS & $x^{2}$ & $p$ \\
\hline There is abuse on antibiotics at present. (Yes) & $\begin{array}{l}1063 \\
(88.6 \%)\end{array}$ & $\begin{array}{l}548 \\
(91.3 \%)\end{array}$ & $\begin{array}{l}515 \\
(85.8 \%)\end{array}$ & 9 & 0.003 & $\begin{array}{l}329 \\
(89.9 \%)\end{array}$ & $\begin{array}{l}256 \\
(85.3 \%)\end{array}$ & 3.2 & 0.073 & $\begin{array}{l}219 \\
(93.6 \%)\end{array}$ & $\begin{array}{l}259 \\
(86.3 \%)\end{array}$ & 7.4 & 0.007 \\
\hline Antibiotic resistance a problem in UAE (Yes) & $\begin{array}{l}534 \\
(44.5 \%)\end{array}$ & $\begin{array}{l}287 \\
(47.8 \%)\end{array}$ & $\begin{array}{l}247 \\
(41.2 \%)\end{array}$ & 5.4 & 0.020 & $\begin{array}{l}152 \\
(41.5 \%)\end{array}$ & $\begin{array}{l}105 \\
(35 \%)\end{array}$ & 3 & 0.085 & $\begin{array}{l}135 \\
(57.7 \%)\end{array}$ & $\begin{array}{l}142 \\
(47.3 \%)\end{array}$ & 5.6 & 0.017 \\
\hline $\begin{array}{l}\text { Abuse of antibiotics the main cause of bacterial } \\
\text { resistance (Yes) }\end{array}$ & $\begin{array}{l}875 \\
(72.9 \%)\end{array}$ & $\begin{array}{l}475 \\
(79.2 \%)\end{array}$ & $\begin{array}{l}400 \\
(66.7 \%)\end{array}$ & 23.7 & 0.000 & $\begin{array}{l}277 \\
(75.7 \%)\end{array}$ & $\begin{array}{l}205 \\
(68.3 \%)\end{array}$ & 4.5 & 0.035 & $\begin{array}{l}198 \\
(84.6 \%)\end{array}$ & $\begin{array}{l}195 \\
(65.0 \%)\end{array}$ & 20 & 0.000 \\
\hline $\begin{array}{l}\text { Antibiotic resistance affect you and your family's } \\
\text { health }\end{array}$ & $\begin{array}{l}824 \\
(68.7 \%)\end{array}$ & $\begin{array}{l}425 \\
(70.8 \%)\end{array}$ & $\begin{array}{l}399 \\
(66.5 \%)\end{array}$ & 2.6 & 0.106 & $\begin{array}{l}247 \\
(67.5 \%)\end{array}$ & $\begin{array}{l}188 \\
(62.7 \%)\end{array}$ & 1.7 & 0.194 & $\begin{array}{l}178 \\
(76.1 \%)\end{array}$ & $\begin{array}{l}211 \\
(70.3 \%)\end{array}$ & 2.2 & 0.139 \\
\hline $\begin{array}{l}\text { Necessary to get more information about } \\
\text { antibiotics }\end{array}$ & $\begin{array}{l}1146 \\
(95.5 \%)\end{array}$ & $\begin{array}{l}583 \\
(97.2 \%)\end{array}$ & $\begin{array}{l}563 \\
(93.8 \%)\end{array}$ & 7.7 & 0.005 & $\begin{array}{l}353 \\
(96.4 \%)\end{array}$ & $\begin{array}{l}286 \\
(95.3 \%)\end{array}$ & 0.53 & 0.468 & $\begin{array}{l}230 \\
(98.3 \%)\end{array}$ & $\begin{array}{l}277 \\
(92.3 \%)\end{array}$ & 9.7 & 0.002 \\
\hline $\begin{array}{l}\text { Need to establish to establish course "Rational } \\
\text { use of antibiotics" at the university level }\end{array}$ & $\begin{array}{l}1061 \\
(88.4 \%)\end{array}$ & $\begin{array}{l}553 \\
(92.2 \%)\end{array}$ & $\begin{array}{l}508 \\
(84.7 \%)\end{array}$ & 16.5 & 0.000 & $\begin{array}{l}335 \\
(91.5 \%)\end{array}$ & $\begin{array}{l}250 \\
(83.3 \%)\end{array}$ & 10.4 & 0.001 & $\begin{array}{l}218 \\
(93.2 \%)\end{array}$ & $\begin{array}{l}258 \\
(86 \%)\end{array}$ & 7 & 0.008 \\
\hline
\end{tabular}

${ }^{*} \mathrm{p}<0.05$; \#Significance; $\mathrm{x} 2$ = chi square test.; $\mathrm{n}(\%)$ : Frequency (Percentage) 


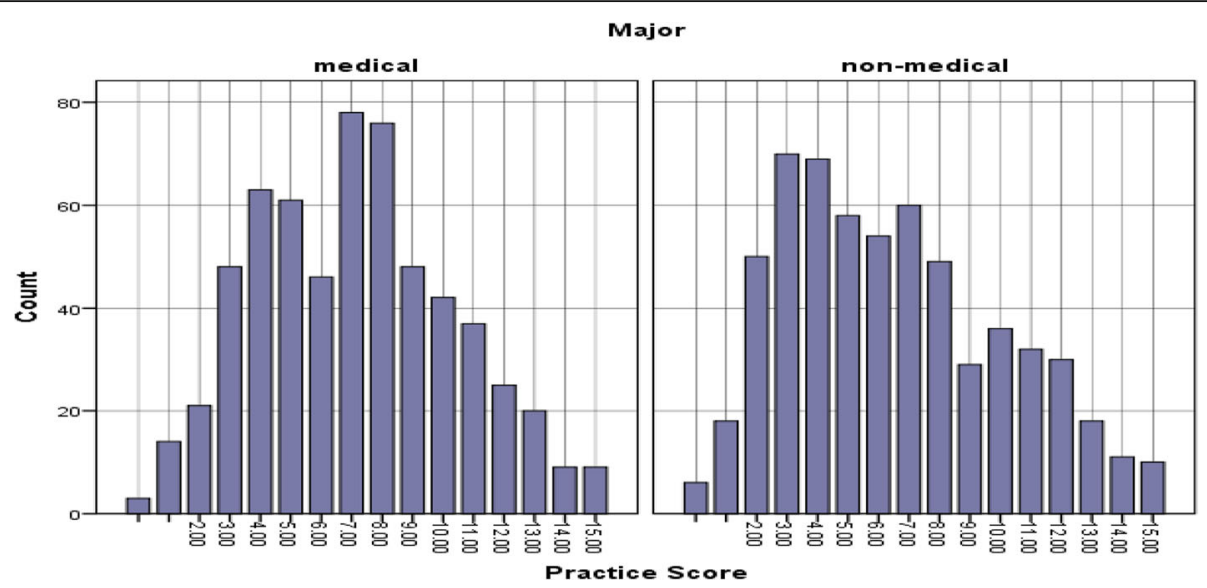

Fig. 3 Histogram of practice score by major. Figure 3 shows the distribution of overall practice scores among medical and non medial students. The values in the $x$ axis represents the total number of correct answers. $Y$ axis represents the count

Table 4 Number and percentage of the questions on the attitude of antibiotic use

\begin{tabular}{|c|c|c|c|c|c|c|c|c|c|c|c|c|c|}
\hline \multirow[t]{2}{*}{ Question (response) } & \multirow{2}{*}{$\begin{array}{l}\text { Total } \\
\%(\mathrm{n} / \\
\mathrm{N})\end{array}$} & \multicolumn{4}{|c|}{ Whole n (\%) } & \multicolumn{3}{|c|}{1 st year $\mathrm{n}(\%)$} & \multicolumn{5}{|c|}{ Final year $\mathrm{n}(\%)$} \\
\hline & & MS & NS & $x^{2}$ & $p$ & MS & NS & $x^{2}$ & $p$ & MS & NS & $x^{2}$ & $p$ \\
\hline $\begin{array}{l}\text { Use antibiotics when having fever } \\
\text { (temperature lower than } 38.5^{\circ} \text { ) }\end{array}$ & $\begin{array}{l}655 \\
(54.6 \%)\end{array}$ & $\begin{array}{l}323 \\
(53.8 \%)\end{array}$ & $\begin{array}{l}332 \\
(55.3 \%)\end{array}$ & 0.27 & 0.602 & $\begin{array}{l}210 \\
(57.4 \%)\end{array}$ & $\begin{array}{l}175 \\
(58.3 \%)\end{array}$ & 0.062 & 0.804 & $\begin{array}{l}113 \\
(48.3 \%)\end{array}$ & $\begin{array}{l}157 \\
(52.3 \%)\end{array}$ & 0.860 & 0.354 \\
\hline Common cold (always, often & $\begin{array}{l}696 \\
(58 \%)\end{array}$ & $\begin{array}{l}319 \\
(53.2 \%)\end{array}$ & $\begin{array}{l}377 \\
(62.8 \%)\end{array}$ & 11.5 & 0.001 & $\begin{array}{l}214 \\
(58.5 \%)\end{array}$ & $\begin{array}{l}190 \\
(63.3 \%)\end{array}$ & 1.6 & 0.201 & $\begin{array}{l}105 \\
(44.9 \%)\end{array}$ & $\begin{array}{l}187 \\
(62.3 \%)\end{array}$ & 16.2 & 0.000 \\
\hline Acute bronchitis (always, often) & $\begin{array}{l}793 \\
(66.1 \%)\end{array}$ & $\begin{array}{l}407 \\
(67.8 \%)\end{array}$ & $\begin{array}{l}386 \\
(64.3 \%)\end{array}$ & 1.6 & 0.20 & $\begin{array}{l}231 \\
(63.1 \%)\end{array}$ & $\begin{array}{l}189 \\
(63 \%)\end{array}$ & 0.001 & 0.976 & $\begin{array}{l}176 \\
(75.2 \%)\end{array}$ & $\begin{array}{l}197 \\
(65.7 \%)\end{array}$ & 5.6 & 0.017 \\
\hline Pneumonia (always, often) & $\begin{array}{l}737 \\
(61.4 \%)\end{array}$ & $\begin{array}{l}391 \\
(65.2 \%)\end{array}$ & $\begin{array}{l}346 \\
(57.7 \%)\end{array}$ & 7 & 0.008 & $\begin{array}{l}213 \\
(58.2 \%)\end{array}$ & $\begin{array}{l}162 \\
(54)\end{array}$ & 1.2 & 0.227 & $\begin{array}{l}178 \\
(76.1 \%)\end{array}$ & $\begin{array}{l}184 \\
(61.3 \%)\end{array}$ & 13.1 & 0.000 \\
\hline $\begin{array}{l}\text { Coughing up yellow/green sputum (always, } \\
\text { often) }\end{array}$ & $\begin{array}{l}771 \\
(64.3 \%)\end{array}$ & $\begin{array}{l}386 \\
(64.3 \%)\end{array}$ & $\begin{array}{l}385 \\
(64.2 \%)\end{array}$ & 0.004 & 0.95 & $\begin{array}{l}229 \\
(62.6 \%)\end{array}$ & $\begin{array}{l}189 \\
(63 \%)\end{array}$ & 0.013 & 0.909 & $\begin{array}{l}157 \\
(67.1 \%)\end{array}$ & $\begin{array}{l}196 \\
(65.3 \%)\end{array}$ & 0.182 & 0.670 \\
\hline Sore throat (always, often) & $\begin{array}{l}822 \\
(68.5 \%)\end{array}$ & $\begin{array}{l}412 \\
(68.7 \%)\end{array}$ & $\begin{array}{l}410 \\
(68.3 \%)\end{array}$ & 0.015 & 0.901 & $\begin{array}{l}260 \\
(71 \%)\end{array}$ & $\begin{array}{l}206 \\
(68.7 \%)\end{array}$ & 0.441 & 0.506 & $\begin{array}{l}152 \\
(65 \%)\end{array}$ & $\begin{array}{l}204 \\
(68 \%)\end{array}$ & 0.584 & 0.459 \\
\hline Cough with fever (always, often) & $\begin{array}{l}879 \\
(73.3 \%)\end{array}$ & $\begin{array}{l}450 \\
(75 \%)\end{array}$ & $\begin{array}{l}429 \\
(71.5 \%)\end{array}$ & 1.8 & 0.171 & $\begin{array}{l}286 \\
(78.1 \%)\end{array}$ & $\begin{array}{l}211 \\
(70.3 \%)\end{array}$ & 5.3 & 0.21 & $\begin{array}{l}164 \\
(70.1 \%)\end{array}$ & $\begin{array}{l}218 \\
(72.7 \%)\end{array}$ & 0.430 & 0.512 \\
\hline $\begin{array}{l}\text { Congested nose with headache (always, } \\
\text { often) }\end{array}$ & $\begin{array}{l}717 \\
(59.8 \%)\end{array}$ & $\begin{array}{l}335 \\
(55.8 \%)\end{array}$ & $\begin{array}{l}382 \\
(63.7 \%)\end{array}$ & 7.6 & 0.006 & $\begin{array}{l}224 \\
(61.2 \%)\end{array}$ & $\begin{array}{l}190 \\
(63.3 \%)\end{array}$ & 0.318 & 0.573 & $\begin{array}{l}111 \\
(47.4 \%)\end{array}$ & $\begin{array}{l}192 \\
(64 \%)\end{array}$ & 14.5 & 0.000 \\
\hline Coughing up white sputum (always, often) & $\begin{array}{l}562 \\
(46.8 \%)\end{array}$ & $\begin{array}{l}275 \\
(45.8 \%)\end{array}$ & $\begin{array}{l}287 \\
(47.8 \%)\end{array}$ & 0.482 & 0.488 & $\begin{array}{l}179 \\
(48.9 \%)\end{array}$ & $\begin{array}{l}141 \\
(47 \%)\end{array}$ & 0.240 & 0.624 & $\begin{array}{l}96 \\
(41 \%)\end{array}$ & $\begin{array}{l}146 \\
(48.7 \%)\end{array}$ & 3.1 & 0.078 \\
\hline $\begin{array}{l}\text { Cough lasting } 2 \text { weeks or more (always, } \\
\text { often) }\end{array}$ & $\begin{array}{l}804 \\
(67 \%)\end{array}$ & $\begin{array}{l}390 \\
(65 \%)\end{array}$ & $\begin{array}{l}414 \\
(69 \%)\end{array}$ & 2.2 & 0.141 & $\begin{array}{l}254 \\
(69.4 \%)\end{array}$ & $\begin{array}{l}212 \\
(70.7 \%)\end{array}$ & 0.126 & 0.723 & $\begin{array}{l}136 \\
(58.1 \%)\end{array}$ & $\begin{array}{l}202 \\
(67.3 \%)\end{array}$ & 4.8 & 0.028 \\
\hline $\begin{array}{l}\text { Stop the use of antibiotics as soon as } \\
\text { complaints lessen (Yes) }\end{array}$ & $\begin{array}{l}534 \\
(44.5 \%)\end{array}$ & $\begin{array}{l}208 \\
(34.7 \%)\end{array}$ & $\begin{array}{l}326 \\
(54.3 \%)\end{array}$ & 47 & 0.000 & $\begin{array}{l}152 \\
(41.5 \%)\end{array}$ & $\begin{array}{l}156 \\
(52 \%)\end{array}$ & 7.3 & 0.007 & $\begin{array}{l}136 \\
(58.1 \%)\end{array}$ & $\begin{array}{l}202 \\
(67.3 \%)\end{array}$ & 57.7 & 0.000 \\
\hline Antibiotic used prescribed by doctor (No) & $\begin{array}{l}433 \\
(36.1 \%)\end{array}$ & $\begin{array}{l}185 \\
(30.8 \%)\end{array}$ & $\begin{array}{l}248 \\
(41.3 \%)\end{array}$ & 14.3 & 0.000 & $\begin{array}{l}98 \\
(26.8 \%)\end{array}$ & $\begin{array}{l}110 \\
(36.7 \%)\end{array}$ & 7.5 & 0.006 & $\begin{array}{l}87 \\
(37.2 \%)\end{array}$ & $\begin{array}{l}138 \\
(46 \%)\end{array}$ & 4.2 & 0.041 \\
\hline $\begin{array}{l}\text { Follow prescription when choose Antibiotic } \\
\text { (No) }\end{array}$ & $\begin{array}{l}317 \\
(26.4 \%)\end{array}$ & $\begin{array}{l}142 \\
(23.7 \%)\end{array}$ & $\begin{array}{l}175 \\
(29.2 \%)\end{array}$ & 4.6 & 0.031 & $\begin{array}{l}78 \\
(21.3 \%)\end{array}$ & $69(23)$ & 0.273 & $\begin{array}{l}0 . \\
601\end{array}$ & $\begin{array}{l}64 \\
(27.4 \%)\end{array}$ & $\begin{array}{l}106 \\
(35.3 \%)\end{array}$ & 3.8 & 0.049 \\
\hline $\begin{array}{l}\text { Used antibiotics without doctor's } \\
\text { Instructions (Yes) }\end{array}$ & $\begin{array}{l}667 \\
(55.6 \%)\end{array}$ & $\begin{array}{l}325 \\
(54.2 \%)\end{array}$ & $\begin{array}{l}342 \\
(57 \%)\end{array}$ & 0.97 & 0.323 & $\begin{array}{l}172 \\
(47 \%)\end{array}$ & $\begin{array}{l}160 \\
(53.3 \%)\end{array}$ & 2.6 & 0.104 & $\begin{array}{l}153 \\
(65.4 \%)\end{array}$ & $\begin{array}{l}182 \\
(60.7 \%)\end{array}$ & 1.3 & 0.263 \\
\hline $\begin{array}{l}\text { Ask the doctor to prescribe for you } \\
\text { antibiotics when you catch a common cold } \\
\text { (Yes) }\end{array}$ & $\begin{array}{l}445 \\
(37.1 \%)\end{array}$ & $\begin{array}{l}185 \\
(30.8 \%)\end{array}$ & $\begin{array}{l}260 \\
(43.3 \%)\end{array}$ & 20 & 0.000 & $\begin{array}{l}131 \\
(35.8 \%)\end{array}$ & $\begin{array}{l}137 \\
(45.7 \%)\end{array}$ & 6.7 & 0.010 & $\begin{array}{l}54 \\
(23.1 \%)\end{array}$ & $\begin{array}{l}123 \\
(41 \%)\end{array}$ & 19.1 & 0.000 \\
\hline
\end{tabular}


About a third of the MS (34.2\%) were confused about whether antibiotics were effective against bacteria or viruses; a similar response was observed in Chinese study [7]. in which $35.5 \%$ of respondents were unaware that antibiotics do not cure viral infections, whereas $83.2 \%$ of respondents in Italian study [16] and 100\% of respondents in Iranian study [12] were conscious that antimicrobial drugs are not appropriate for viral infections. Moreover, two-thirds of the MS (65.8\%) believed that antibiotics can speed up the recovery of common cold, cough and a number of other related illnesses arising from viral infections which is relatively high compared to other relevant studies $[7,14]$. Another study also found in a telephone survey that $27 \%$ of respondents with common cold believed that antibiotics made them recover more quickly whereas in Jamshed et al. [13], only $4.9 \%$ believed that common cold and cough should always be treated with antibiotics to make the patient recover faster. This study also demonstrated that nearly half of the MS (47\%) perceived that antibiotics are obtainable without interference of a doctor at drug store or at pharmacies. This poor knowledge about antibiotic use reflects the need to promote awareness on this topic during course curriculums.

Regarding the attitude of medical and non-medical students towards antibiotics use, our results showed that overall MS scored higher than NS $(p=0.000)$; this was consistent with other studies on college students [7, 8]. However, a study in Trinidad and Tobago [9] showed a negative attitude of pharmacy students towards antibiotic use and resistance while the [12], majority of medical interns $(73.1 \%)$ had a moderate attitude towards antibiotic resistance etiology [12],

Our results also showed that first-year MS performed better than first-year NS in their attitude towards antibiotic use $(p=0.001)$ while no significance difference was found between first-year medical and non-medical students in Huang et al. [7]. Moreover, this study showed that final year MS performed better than NS ( $p=0.000)$, and this was similar to Huang et al. [7]

Our study showed that $91.3 \%$ of medical students believed that thereis an abuse of antibiotics at present; this was consistent with Huang et al. [7] which showed that 90.1\% of respondents are aware of this fact. However only $47.8 \%$ of our respondents believed that it is a national problem. On the other hand, a study among interns and senior physicians in France showed that 98\% of physicians considered antibiotic resistance a national problem [25]. Furthermore, 94\% of medical students in Abbo et al. [26] 83\% of the Chinese medical students in Huang et al. [7] and $88.65 \%$ of Indian medical students in Khan and Banu [14] shared this view. Therefore, it is important to organize educational campaigns to address these issues.
Minen et al. [27] in a KAP survey on antibiotic use among 304 MS in America reported that more than 75\% of the students preferred more education on antibiotics which was consistent with $89 \%$ of medical students in Huang et al. [7] and 90\% of medical students in Abbo et al. [26] These studies support our findings which concludes that $97.2 \%$ of MS believed that it is necessary to get more education about antibiotics.

With regard to the practice of antibiotic use, our result showed that overall MS scored significantly higher than NS $(p=0.002)$. The findings are in line with the results presented by the study in Chennai [8] and India [14]. Another study in a school of medicine in Italy [16] concluded that healthcare profession students did not practice what they knew. Moreover, the practice towards antibiotics resistance and prescribing was in moderate range among students [12].

Our study showed also that there were no significance difference between first-year medical and non-medical students regarding the practice of antibiotic usage $(p=$ 0.232); this was in accordance with Huang et al. [7] Additionally, this study showed that final year MS performed better than final year NS on practice of antibiotic usage $(p=0.001)$.

An alarming finding was the one related to the overuse of antibiotics for various symptoms of respiratory tract infection among medical students. For instance, more than half of the MS would use antibiotics more frequently for acute bronchitis, pneumonia, coughing up yellow/green sputum, cough, fever, congested nose with headache and cough lasting two weeks or more. This was similar to the study in Nigeria which showed a high rate of consumption of antibiotics among university undergraduates [15]. The study has also revealed that $45.8 \%$ of MS showed high frequency of antibiotic usage when coughing up white sputum, and $54.2 \%$ of them had used antibiotics without doctor's instructions. Our study showed that $53.2 \%$ of MS used antibiotics for common cold and $68.7 \%$ of them used antibiotics for sore throat while in Huang et al. [7] 13.6 and 15.3\% of MS used antibiotics for common cold and sore throat, respectively. Moreover, in Khan and Banu [14] 38.1\% of respondents agreed to take antibiotics to prevent further serious illnesses when they had common cold. On the other hand, Jorak et al. [12] showed that $100 \%$ of the interns knew that antibiotics were not recommended to treat common cold and viral infections, and this was consistent with Scaioli et al. [16] which showed that $99.62 \%$ of respondents did not take antibiotics for cold or sore throat as well as with Jamshed et al. [13] which found that $95.1 \%$ of the participants aware that common cold and cough should not be treated with antibiotics and Ahmad et al. [9] which concluded that only $8.3 \%$ respondents agreed to antibiotics' help in the prevention 
of illness during common cold and flu. This implies that the education that medical students rely upon is not sufficient and that better education is required on the appropriate use of antibiotics to improve their practice towards antibiotics and their use.

\section{Conclusions}

Although this study's findings showed that overall MS performed better than NS on the KAP of antibiotic use, there are some potential causes of antibiotic abuse; this implies that education imparted by our universities on this issue was weak and adding some courses on rational antibiotic use in the medical curriculum is urgently required.

\section{Abbreviations}

GCC: Gulf Cooperation Council; KAP: Knowledge, attitude and practice;

UAE: United Arab Emirates

\section{Acknowledgements}

Not applicable.

\section{Funding}

No funding were used to assist in the preparation of this study.

\section{Availability of data and materials}

The datasets generated during and/or analysed during the current study are available from the corresponding author on reasonable request.

\section{Authors' contributions}

$\mathrm{NH}$ and AJ designed the study. OJ and MS responsible for data collection. AJ analyzed and interpreted the data. AJ and MS drafted the manuscript. All authors reviewed and approved the manuscript.

\section{Ethics approval and consent to participate}

The study was approved by Ajman university's research ethical committees and an approval letter was obtained to allow the researcher to distribute and collect the questionnaires among $\mathrm{AU}$ students. The participation of the students in this study was entirely voluntary and without compensation. Before data collection, the purpose of the survey was explained, and they were also informed that the completion and submission of the questioner would be taken on their consent and all students signed the informed consents.

\section{Consent for publication}

Not applicable.

\section{Competing interests}

All authors declare that they have no competing interests.

\section{Publisher's Note}

Springer Nature remains neutral with regard to jurisdictional claims in published maps and institutional affiliations.

\section{Author details}

${ }^{1}$ College of Pharmacy and Health Sciences, Ajman University, Ajman, UAE. ${ }^{2}$ College of Dentistry, Ajman University, Ajman, UAE.

Received: 8 February 2019 Accepted: 22 April 2019

Published online: 06 May 2019

\section{References}

1. Fischbach MA, Walsh CT. Antibiotics for emerging pathogens. Science. 2009: 325:1089-93.

2. Gyssens IC. Quality measures of antimicrobial drug use. Int J Antimicrob Agents. 2001;17:9-19.
3. WHO. World Health Day. Antimicrobial resistance: no action today, no cure tomorrow. 2011. http://www.who.int/mediacentre/news/statements/2011/ whd_20110407/en/index.html.

4. Dantas G, Sommer M. How to fight back against antibiotic resistance. Am Sci. 2014;102:41-51.

5. Tunger O, Karakaya Y, Cetin CB, Dinc G, Borand H. Rational antibiotic use. J Infect Dev Ctries. 2009:3:88-93.

6. Parimalakrishnan AA, Mohanta GP, Patel I, Manna PK. A study on utilization pattern of higher generation antibiotics among patients visiting community pharmacies in Chidambaram, Tamil Nadu at South India. Int J Pharm. 2012;2:466-71.

7. Huang Y, Gu J, Zhang M, Ren Z, Yang W. Chen Y, et al. Knowledge, attitude and practice of antibiotics: a questionnaire study among 2500 Chinese students. BMC Med Educ. 2013:13:163.

8. Ganesh M, Sridevi S, Paul C. Antibiotic use among medical and Para medical students: knowledge, attitude and its practice in a tertiary health care Centre in Chennai - a scientific insight. Int J Sci Res. 2014;3:332-5.

9. Ahmad A, Khan MU, Patel I, Maharaj S, Pandey S, Dhingra S. Knowledge, attitude and practice of b.Sc. Pharmacy students about antibiotics in Trinidad and Tobago. J Res Pharm Pract. 2015;4:37-41.

10. Kumar BPS, Santhosh YL, Ahamed MG, Naveen M. Survey on knowledge towards antibiotics among the nursing students. Int J Pharm Pharm Sci. 2011:3:227-9.

11. Prakasam KCA, Kumar NS, Ramesh J. Students' knowledge of antibiotics: a cross sectional study of students in Tamil Nadu. Int J Pharm Pharm Sci. 2011;3:232-3.

12. Jorak A, Keihanian F, Saeidinia A, Anwar M, Sarfraz M. A cross sectional study on knowledge, attitude and practice of medical students toward antibiotic resistance and its prescription, Iran. Adv Environ Biol. 2014;8:675-81.

13. Jamshed SQ, Elkalmi R, Rajiah K, Al-Shami AK, Shamsudin SH, Siddiqui MJ, et al. Understanding of antibiotic use and resistance among final-year pharmacy and medical students: a pilot study. J Infect Dev Ctries. 2014;8:780-5.

14. Khan AKA, Banu G, Reshma KK. Antibiotic resistance and usage-a survey on the knowledge, attitude, perceptions and practices among the medical students of a southern Indian teaching hospital. J Clin Diagn Res. 2013;7:1613-6.

15. Abimbola I. Knowledge and practices in the use of antibiotics among a group of Nigerian University students. Int J Infect Control. 2013;9:1-8.

16. Scaioli G, Gualano MR, Gili R, Masucci S, Bert F, Siliquini R. Antibiotic use: a crosssectional survey assessing the knowledge, attitudes and practices amongst students of a school of medicine in Italy. PLoS One. 2015;10:e0122476.

17. Polit DF, Beck CT, Owen SV. Is the CVI an acceptable indicator of content validity? Appraisal and recommendations. Res Nurs Health. 2007;30:459-67.

18. Lawshe C. A quantitative approach to content validity. Pers Psychol. 1975; 28:563-75.

19. Tilden V, Nelson C, May B. Use of qualitative methods to enhance content validity. Nurs Res. 1990;39:172-5.

20. Suaifan G, Shehadeh M, Darwish D, Al-liel H, Yousef A-MM, Darwish RM. A cross-sectional study on knowledge, attitude and behavior ralated to antibiotic use and resistance among medical and non-medical university students in Jordan. Afr J Pharm Pharmacol. 2012;6:763-70.

21. Shehadeh M, Suaifan G, Darwish RM, Wazaify M, Zaru L, Alja'fari S. Knowledge, attitudes and behavior regarding antibiotics use and misuse among adults in the community of Jordan. A pilot study. Saudi Pharm J. 2012;20:125-33

22. Humphreys H, Dillane T, O'Connell B, Luke LC. Survey of recent medical graduates' knowledge and understanding of the treatment and prevention of infection. Ir Med J. 2006;99:58-9.

23. Ibia E, Sheridan M, Schwartz R. Knowledge of the principles of judicious antibiotic use for upper respiratory infections: a survey of senior medical students. South Med J. 2005:98:889-95.

24. Azevedo MM, Pinheiro C, Yaphe J, Baltazar F. Portuguese students' knowledge of antibiotics: a cross-sectional study of secondary school and university students in Braga. BMC Public Health. 2009;9:359.

25. Nyquist AC, Gonzales R, Steiner JF, Sande MA. Antibiotic prescribing for children with colds, upper respiratory tract infections, and bronchitis. JAMA. 1998:279:875-7.

26. Abbo LM, Cosgrove SE, Pottinger PS, Pereyra M, Sinkowitz-Cochran R, Srinivasan A, et al. Medical students' perceptions and knowledge about antimicrobial stewardship: how are we educating our future prescribers? Clin Infect Dis. 2013:57:631-8.

27. Minen MT, Duquaine D, Marx MA, Weiss D. A survey of knowledge, attitudes, and beliefs of medical students concerning antimicrobial use and resistance. Microb Drug Resist. 2010;16:285-9. 